\title{
The United Nations
}

\section{Managing and Reshaping a Changing World Order}

\author{
Amitav Acharya \\ UNESCO Chair in Transnational Challenges and Governance, American \\ University, Washington, DC, USA; Berggruen Institute Fellow, Los Angeles, \\ CA, USA \\ aacharya@american.edu
}

\author{
Dan Plesch \\ Centre for International Studies and Diplomacy, SOAS University \\ of London, London, UK \\ dp27@soas.ac.uk
}

\section{Introduction}

Gambia is very, very poor ... they are kept down because of exploitation ... [We need to be] against the exploitation of the poor by the rich-by governments as well as individuals. I think we can get somewhere if we keep that idea of being against ... exploitation everywhere. It will be an awfully good thing for all of us. ${ }^{1}$

Franklin D. Roosevelt, US president, in 1944

As the war has developed and the danger of a possible victory of the fascist powers has receded, there has been a progressive hardening and a greater conservatism in the leaders of the United Nations. The four freedoms and the Atlantic charter, vague as they were and limited in scope, have faded into the background, and the future has been envisaged more and more as a retention of the past ... [T] he hundreds of millions of Asia and Africa ... have become increasingly conscious of themselves and their destiny ... They welcome all attempts at world co-operation and the establishment of an international order, but they wonder and suspect if this may not be another device for continuing the old domination. ${ }^{2}$

Jawaharlal Nehru, Indian anticolonial leader and future prime minister, in 1944

1 Roosevelt 1944a. See also Roosevelt 1944b.

2 Nehru, 2003, 546-547.

(C) AMITAV ACHARYA AND DAN PLESCH, 2020 | DOI:10.1163/19426720-02602001

This is an open access article distributed under the terms of the $\mathrm{CW}_{\mathrm{B}} \mathrm{4}$. plicense. 
The future does not belong to globalists; it belongs to patriots. Donald Trump, US president in $2019^{3}$

Although the UN was conceived as a "universal" organization, its origin and maintenance has been credited almost exclusively to the liberal international order (LIO) created and dominated by the United States and the West. As this narrative goes, the UN and its family of institutions, like the International Monetary Fund (IMF), World Bank, and General Agreement on Tariffs and Trade (GATT), were established as a US-led Western project in shaping which Western liberal norms and institutional choices played the leading, almost exclusive role. This view conflates universalism with hegemonic stability. Hence, it is not surprising that there is much pessimism today about the future of UN and multilateralism. Since the UN and the LIO are viewed as one and the same, the decline of the LIO is seen as leading to the collapse of universalism and multilateralism.

But this view is misleading. The above-cited words of Franklin D. Roosevelt (FDR) and Jawaharlal Nehru, both expressed in 1944 but from radically different vantage points - the former at the height of his political life as the leader of the most powerful nation on Earth, the other in prison for his struggle against British colonial rule-suggest that a very different view of the relationship between universalism and the LIO is warranted.

A little historical background is in order. To say that 2020 marks the $75^{\text {th }}$ anniversary of the UN, hence this special issue of Global Governance, is only a half-truth. The formal origins of the UN we know today should be dated from New Year's Day 1942 with the Declaration by United Nations of twentysix states, rather than the orthodox account that starts with the conversations of the future Permanent Five at Dumbarton Oaks in 1944 and the San Francisco conference that created the UN Charter in $1945 .{ }^{4}$ In this 1942 declaration, FDR insisted that China be included as one of the top four powers, and that still colonized India be treated as if it were independent. How indeed could Nehru refer in 1944 to the development of the United Nations up to that time, when the UN Charter was not agreed on until the following year? While Nehru would soon grow concerned about the loss of the original UN spirit and the return of power politics, ${ }^{5}$ both FDR and Nehru (who is sometimes labeled in the West as a liberal despite his very obvious socialist leanings) viewed universalism in broader and more inclusive terms than FDR's successors, starting with Harry

3 Trump 2019.

4 Plesch 2010a; Plesch and Weiss 2015.

5 Nehru 2003, 539. 
S. Truman. Moreover, Nehru's fears in 1944 would soon be justified as the USand Soviet Union-led blocs would quickly sideline the fundamental spirit of universalism for the sake of their ideological and geopolitical interests in the Cold War.

Taking this as the stating point, we argue in this essay against the frequent conflation between the LIO and universalism. This is for three main reasons. First, the LIO was not a universal order. Indeed, after Trump's election to the US presidency, some of the leading proponents of the LIO concede this. A key advocate, Joseph S. Nye, writes that the LIO "was largely limited to a group of like-minded states centered on the Atlantic littoral" and "did not include many large countries such as China, India, and the Soviet bloc states, and ... did not always have benign effects on nonmembers." ${ }^{6}$ This echoed Amitav Acharya's earlier contention that not only the universality of the LIO was a "myth" since "the Soviet bloc, China, India, Indonesia, and a good part of the 'third world' were outside of it," but also that the LIO was "not so benign for many outside of it, especially in the developing world." ${ }^{7}$ Hence, the LIO should be seen as an "international order, but not the world order, of the post-World War II period." This point is reinforced by the presence of these non-Western states in the power structures of the United Nations, the dynamics between a Western LIO and the wider UN system being a key feature of the past 75 years.

A second fact that questions the conflation of the UN and the LIO is that the former was founded with both liberal and nonliberal ideas, including socialist, communitarian, and conservative ones. Some of these spilled over into the Universal Declaration on Human Rights (UDHR). While Eleanor Roosevelt chaired the commission drafting the declaration in 1947, the vice-chairman was Peng Chung Chang of China (then Republic of China), and Charles Malik of Lebanon served as rapporteur. Malik was instrumental in drafting the terms of the declaration and defending it against competing communitarian ideas (which came from China). As Rebecca Adami reminds us, Islamic and other non-Western women also played important roles in the UDHR. ${ }^{8}$ Mrs. Roosevelt recalled in her memoirs:

Dr. Chang was a pluralist and held forth in charming fashion on the proposition that there is more than one kind of ultimate reality. The Declaration, he said, should reflect more than simply Western ideas and Dr.

6 Nye 2017, 12.

7 Acharya 2014, 40.

8 Adami 2018. 
Humphrey [director of the UN's Human Rights Division and a member of the commission], would have to be eclectic in his approach. His remark, though addressed to Dr. Humphrey, was really directed at Dr. Malik, from whom it drew a prompt retort as he expounded at some length the philosophy of Thomas Aquinas. Dr. Humphrey joined enthusiastically in the discussion, and I remember that at one point Dr. Chang suggested that the Secretariat might well spend a few months studying the fundamentals of Confucianism $!^{9}$

What is interesting here is that both sides of what came to be known as the "universalism-relativism" debate in human rights were at this point led by non-Western countries. But there were also ideational differences within the West, including the United States. In the formative years of the LIO, the United States was led by both Democratic (Roosevelt and Truman) and Republican (Dwight D. Eisenhower) administrations, with marked different views about multilateralism and universalism, which is sometimes underemphasized by the proponents of the LIO. As noted, FDR's conception of international order was more inclusive, whereas the Truman/Eisenhower approach was a narrower, more geopolitical and US-centric version. African and African American human rights presented an integrated threat to white Washington with some amelioration in the FDR era. Increasingly, as the Cold War progressed, the LIO became associated with US hegemony, neocolonialism, and then neoliberalism, thereby vindicating Nehru.

While "exploitation" was the key concept that Franklin Roosevelt urged on delegates to the 1944 meeting of the International Labour Organization in Philadelphia, no US president since has expressed such a view. The UN Charter in its economic and social sections, as well as the founding purposes of the World Bank and the IMF, also made social security, full employment, and labor conditions strategic objectives. But these were to give way to development through growth in gross domestic product (GDP) and on channeling strategic aid to anticommunist postcolonial states. Hence, liberalism in the LIO today is a far more restricted concept than liberalism was in 1944; FDR himself avoided labels.

Finally, the UN of the $1942-1945$ era had a larger constituency of agency than the US-centric narrative of the founding of the LIO. That narrative eclipsed the contemporary reality. While Nehru was writing from prison about "the hundreds of millions of Asia and Africa ... [welcoming] all attempts at world co-

9 United Nations, no date. 
operation and the establishment of an international order,"10 scores of diplomats and soldiers from Latin America, Asia, Africa, and the Middle East were already playing and would continue to play an active role in building the UNbased international order, alongside the Western countries. Among these were Asian and other non-Western contributions to the founding structures of the $\mathrm{UN}$, and to issues ranging from war crimes policy to the status of women.

To understand these forgotten or suppressed dynamics, it is first necessary to engage in archaeology of the origins in the UN in the early 1940s.

There is no question that US, and to some degree British and Soviet, leadership drove the wartime UN from 1942 onward, but non-Western agency also shaped them and is imbedded in the core foundations of UN institutions and policy.

During the war, nationalist China was represented at multilateral conferences on food, economic, and monetary policy, war crimes and on the UN Organisation created in 1945. China's activism in international criminal law in World War II was extensive and early in a period when Anglo-American activism was conflicted and late, despite the dominance of the Nuremberg narrative. In January 1942, the European refugee governments in London issued a joint statement at St. James's Palace on punishment for war crimes. This made clear that the crimes of the Nazis required innovation in international law and sought to create an international system of peer review to provide legitimacy to national prosecutions. China immediately expressed support, declaring that the subjugation of peoples through the dissemination of narcotics should be considered a crime and its intention to initiate proceedings against the Japanese. Neither the United Kingdom, the United States, or even the USSR ever adhered to the declaration. Nevertheless, by the end of 1942, the AngloAmerican governments had been pressured by these states and their own civil society to agree to create a UN commission to investigate war crimes. ${ }^{11}$ China was a founding member of the commission, and by the summer of 1944, had created a war crimes subcommission in Nanking that included eleven allies and considered thousands of cases. The commission was innovative in developing international law. For example, it routinely endorsed the sporadic charges for rape brought by its member states.

\footnotetext{
$10 \quad$ Nehru, 2003, 546.

11 Plesch 2010b; Plesch and Weiss 2015.
} 
India, as noted, was considered as an independent state in the Declaration by United Nations of January 1942 and, consequently, participated in the intrawar UN Conferences on Food and Agriculture in 1943, on postwar aid and reconstruction in 1944, and at Bretton Woods and San Francisco on a similar basis as states such as Australia, despite not being independent. By the time of the first session of the UN General Assembly, a transitional Indian government had had six years of experience in multilateral negotiations. Before it was an independent state, India famously protested South African racial laws in 1946 at the first meeting of the General Assembly. India had already, by this time, helped lead innovation in international criminal law. These efforts included an Indian-US joint effort in proposing joint military tribunals — subsequently deployed most famously at Nuremberg and Tokyo, but also in hundreds of trials across Europe and Asia. India supported the commission's decision to support war crimes indictments against Italians, brought by Emperor Haile Selassi's Ethiopia. Italy refused to extradite the accused to Ethiopia according to its obligations under the 1947 peace treaty. Ethiopian agency at this time and its suppression are the opposite of twenty-first century complaints from the West over African inaction on war crimes.

The issue of gender equality is often regarded as a white Western conception. In reality from the UN Charter through the UDHR, non-Western agency has been important and at times crucial to the development of gender equality in the international system. Conventional wisdom tends to attribute these achievements to Eleanor Roosevelt; or, when considering the UN Charter, to the South African field marshal Jan Smuts's Preamble to the Charter and the presence of a female US delegate Virginia Gildersleeve. Recent research reveals a radically different picture. ${ }^{12}$ At San Francisco as delegates gathered for the UN Conference on International Organization in April 1945, there was a women's lobby. The negotiating record and contemporary accounts concur in attributing gender equality in the Charter to the role of two of the four women who were formal national delegates, Minerva Bernardino of the Dominican Republic and crucially the Brazilian, Bertha Lutz. Invoking the contribution of women to victory in the war, Lutz led the battle in committee, where she was credited with "Lutzwaffing" her opponents. Without gender equality in the Charter, and especially in Article VIII governing the UN's own processes, it is hard to see any roots taking hold from which the present growth in gender equality could have grown. 
Non-Western and female representation is also underreported in foundational accounts of the Universal Declaration of Human Rights. Adami has amended the record to show the role of women, including Bernardino, Hansa Mehta from India, and Begum Shaista Ikramullah from Pakistan, who succeeded in securing gender equal language in the declaration. ${ }^{13}$

These insights into the foundations of the UN structures and ideas are indicative and not exhaustive. A broader and deeper study should examine how Liberia and Haiti, among others, sent funds to help rebuild Europe and China. The belated unearthing of non-Western agency in the creation of the UN system carries a broader significance as we interpret the intellectual archaeology. The victory over fascism is almost universally now recorded as an Allied rather than a UN victory as it was at the time, and the national military contributions are correctly given pride of place. But they have overshadowed the egalitarian and, at times, transnational ideology that motivated peoples and troops.

\section{Back to the Present: The Changing World Order}

World order refers to the broad interplay of power distribution, ideas, institutions, and interactions that characterize a significant portion of the world at a given time. The contemporary world order is increasingly defined by the following characteristics:

- The end of the unipolarity. There are severe constraints on any single power-either the United States or China-exercising global hegemony in the manner of Britain before World War I and the United States after World War II. The caveat is that US military power might remain unmatched

- The proliferation of consequential actors. These are not just great powers or "rising/emerging" powers, but also international and regional bodies, nonstate groups, corporations, and people's networks empowered by social media. This does not mean the "end of the nation-state," but more complexity than in the age of European multipolarity or Cold War bipolarity.

- Changing nature of interdependence, not just in trade, but also covering investment, finance, and production networks and supply chains. While under attack by reactionary movements, globalization is not over, but may be taking on new forms, driven by the rising powers such as China and India.

13 Adami 2018. 
- Devolution, fragmentation, and pluralization of global governance. Global governance has never been universally admired, nor has it been a linear process. The demand for global governance varies with time and issue areas, some areas like trade may see less demand while others like climate may see more. The architecture of global governance is changing; the big multilaterals of the UN system are no longer the only game in town, but are joined (not displaced) by new and complex types of governance, comprising formal institutions, networks, and hybrid public-private partnerships.

- Persistence of cultural, ideological, and political diversity. There is no "end of history"; world politics is shaped by multiple ideational and ideological undercurrents-liberal, conservative, communitarian, and radicalchallenging the idea of a singular approach to modernity as developed by the West.

- Transnational imperilment. While there remain disagreements over the nature and impact of new threats, there is at least a growing realization, backed by evidence (most recently the global COVID-19 outbreak) that the major threats to global stability are not conventional interstate wars but intrastate conflicts and "nontraditional" threats such as climate change and other forms of environmental degradation, forced migration, pandemics, drug trafficking, people smuggling, violent extremism, terrorism, and transnational crime. These are complex sources of conflict that may originate from within the boundaries of a state, but have a regional or global impact, sometimes with great rapidity

This leads to another point, the emerging world order is not a simply a return to unipolarity, bipolarity, multipolarity, or liberal hegemony. A word about multipolarity here since this is the default term of most geopolitical pundits these days in describing the new world order. Traditionally, "multipolarity," according to Barry Posen, refers to the "relatively equal distribution of capabilities ... with three or more consequential powers." ${ }^{14}$ Similarly, Zaki Laidi defines "multipolarity" as "a system in which power is distributed at least among 3 significant poles concentrating wealth and/or military capabilities and able to block or disrupt major political arrangements threatening their major interests". In his formulation, "a pole is an actor capable of producing order or generating disorder ... which has influence on global outcomes beyond its own borders." ${ }^{15}$ Yet we live in a world in which the ability of "producing order or generating disorder" to influence "global outcomes" lies not just with great pow-

14 Posen 2009, 350.

15 Laidi. 
ers (even among these, power distribution remains asymmetric, rather than equal), but also nonstate actors such as institutions, corporations, extremists, and social movements using material (wealth and military) and nonmilitary (especially new technologies such as artificial intelligence and others that have at least a dual use) and ideational resources. Past multipolarity was managed by great powers through a balance of power system, including the nineteenthcentury Concert system, colonialism, and with few multilateral institutions. Yet the new world order is shaped by a greater variety of "consequential" actors. ${ }^{16}$

Hence, the twenty-first-century world order can be defined as a world order in which no single power or ideology dominates globally, which is culturally and politically diverse yet deeply interconnected and interdependent, and whose main players-both the makers and breakers of order-are not just states and the great powers, but also a variety of other consequential actors national and international, state and nonstate.

\section{Reigniting Multilateralism}

What is the future of the UN, and multilateralism more generally, in this changing nature of world order? Challenges to multilateralism and the UN abound. Another challenge is reactionary politics in Western nations. Yet there are grounds of hope for the future of the UN.

First, the demand for multilateralism has varied. In the United States, both the Ronald Reagan and George W. Bush administrations retreated from multilateralism, although to a lesser extent than Donald Trump. Domestic politics can be a double-edged sword insofar as support for the UN is concerned. Here is a striking example: despite Trump's rhetoric against multilateralism, the US Congress has kept funding for the UN stable. ${ }^{17}$

Second, the demand for multilateralism is driven by a combination of strategic, normative, and functional logics. ${ }^{18}$ If the idea of multilateralism as good and desirable for its own sake is discarded, then the strategic and functional reasons for it might persist or even increase to compensate for it. Rising pow-

16 The terms "Multiplex" and "G-Plus" are coined by Acharya, to distinguish multipolarity from the emerging world order. Acharya 2014; Acharya 2017.

17 In February 2019, the US Congress restored most of the Trump administration's cuts to the US funding for the UN, except to peacekeeping, which was 3 percent lower than the traditional US share of 27.9 percent of the UN peacekeeping budget. Goldberg 2019 . 
ers such as China and India, along with traditional powers, see multilateralism as important to their status and influence.

Transnational challenges defy national boundaries, which no single nation or bloc can solve on its own. This reality does not itself sustain multilateralism since not all agree on its importance. But this also means that the need and demand for multilateralism is not just a moral imperative, but also a practical necessity.

Third, the demand for multilateralism varies across issues. A study published in 2016 showed that while demand for global governance might be strengthening in the need to address climate change, human rights, global security governance, and mass atrocities, it is weakening in health, trade, and even possibly finance (where it may be static after having risen in the immediate aftermath of the 2008 financial turmoil). Also, in some areas such as trade and finance, the demand for global governance is crisis driven. Understanding these variations across issue areas and time is important in generalizing and devising ways of addressing challenges to the $\mathrm{UN}$ and its role in global governance. ${ }^{19}$

Fourth, while the decentering and fragmentation of multilateralism can create confusion, increase transaction costs, and possibly lead to reduced effectiveness of existing UN-based global governance institutions and mechanisms, it is also clear that fragmentation is driven by the demonstrated weaknesses and failures of existing mechanisms and their lack of normative and performance legitimacy. In this context, the emergence of new actors and frameworks of multilateralism due to the proliferation of new actors is not necessarily at the expense of the UN. This is not a zero-sum game, but a positive-sum one, one that offers considerable scope for divisions of labor.

For example, human rights laws today are enforced not only in international courts, but also through criminal prosecutions in domestic courts of former state officials, where both international law and domestic criminal law are used. The International Criminal Court has been joined by more than two dozen international enforcement courts in the world enforcing human rights law. This promotes human rights around the world. Some bilateral and plurilateral arrangements create stricter standards for intellectual property protection and tougher enforcement penalties for intellectual property infringement than existing Trade-Related Aspects on Intellectual Property (TRIPs) measures. Hence, they support the goals of global trade governance, if not its primary multilateral institution. In finance, a key development is the emergence of "cooperative decentralization" as a form of fragmentation, resulting from the

19 Acharya 2016. 
2008-2009 financial crisis. ${ }^{20}$ These regional and plurilateral financial arrangements worked with the IMF. Opinion is divided on the benefits and costs of this form, with critics skeptical of their ability effectively contain crises while others see them as durable and positive forces in global financial regulation.

In climate change, the proliferation of initiatives does not replace or weaken the UN's role. At the same time, as academic literature has pointed out, institutions are sticky-it's easier to modify them than to create new ones. ${ }^{21}$ Hence, as existing multilateral institutions come under pressure, they will not be displaced, but new arrangements may emerge with respect to aspects of environmental degradation such as industrial pollution and deforestation. Fragmentation can be creative, leading to innovation in problem solving.

Fifth, despite the current pessimism about global governance, the demand for multilateral action is wider than ever before-a key factor supporting the future of the UN. A good deal of recent literature on agency is concerned with the proliferation of actors, especially looking beyond the state-centric focus of the early literature to capture the role of transnational civil society and the private sector, and so forth. But the issue of agency goes well beyond bringing the nonstate actors in. Equally important is that the US role in creating and maintaining the global governance architecture has been more limited and less positive while the contribution of others including Europeans and, as discussed earlier in this article, the developing countries (and the weaker actors more generally) is less appreciated but more substantial and extensive than is usually captured in the academic literature and policy debate. This is clear in the area of human rights, Responsibility to Protect $\left(\mathrm{R}_{2} \mathrm{P}\right)$, climate change, and internet governance, the last being an understudied area where the US role has come under intense criticism after the revelations by intelligence analyst David Snowden in 2013 of massive and systematic US surveillance of the internet. ${ }^{22}$

However, these factors are not enough to the keep the UN going in the long term. Critically, leaders must pay more attention to selling the benefits of multilateralism and the UN to domestic audiences. To this end, a comprehensive and nonpartisan assessment audit of the benefits of multilateralism for countries is necessary to reduce political partisanship and bias in the debate over the necessity and importance of the UN.

There are many proposals about UN reform, but lack of space precludes a detailed discussion of these. ${ }^{23}$ Proposals that seek to the alter the fundamen-

\footnotetext{
$20 \quad$ Helleiner 2016, 178.

21 Keohane 1984.

22 Cogburn 2016, 269-270.

23 See, for example Stimson Center, 2029; de Coning and Peter 2019; United Nations, 2015.
} 
tal structure of the UN, no matter how desirable for justice and fairness, seem rather unlikely. These include reform of the Security Council, where the veto protects the status quo. Obsessing with them is neither productive nor necessary for the UN to remain relevant and important. There are other ideas, such as expanding the voting share in multilateral institutions such as the IMF and the World Bank of countries that are increasingly wealthy and able to contribute to the budget. This will become more achievable as the global economic shift continues. The most consequential and realizable proposals for reform may be the least publicized or more low-key ones. These include increasing the space for political solutions to accompany military and technical aspects of peace operations, forging greater partnerships between the UN and regional bodies, and adapting the UN Secretariat to be more "field-oriented" and "peoplefocused." 24

The UN was designed and has grown organically as a confederation of bodies around the core of the Security Council, General Assembly, and Secretariat. There remains scope for reform and reorganization with, for example, unified financial and human resource functions. Increasing national and civil society engagement provides an additional strategy. Engagement of crowdfunding of core UN budgets is one idea. Another is matching the still dominant US financial contribution with those from wealthy states. Qatar, Norway, and Lichtenstein, to name but three, could pick up the entire UN core budget. Tripling, not cutting, the budget would be a start.

UN military and civil intervention forces remain a pale shadow of the founders' vision. Few remember that, sincerely or not, Winston Churchill, called for the British air force to have units at the disposal of the Security Council in his Iron Curtain speech in Fulton, Missouri. Today, even UN peacekeeping is an essentially rolling temporary affair. States should commit standby forces for UN missions.

The global democratic deficit undermines the legitimacy of the UN along with the other international governmental organizations. The occasional presence of nongovernmental organizations at the Security Council and in profusion around most UN bodies is not enough since many are corporate fronts or dependent on government and agency funding from the bodies they are pressuring. At the international level, states send only officials selected from an elite bureaucracy answerable to the nation-state government. Occasionally, political appointees are sent, and elected officials turn up for the grand occasion. National electorates could start to directly elect their nations' representatives 
to the key decisionmaking bodies, which would enhance the legitimacy of the bodies themselves.

Albert Einstein famously observed the bomb had changed everything except the way people think. ${ }^{25}$ In extremis, Churchill, Joseph Stalin, and FDR became Kantians of necessity seeking to prevent further world wars even before the atom bomb. FDR's central driver for the UN was to have the UN established during the war while such existential threats remained dominant. Today, the world faces a different, but no less powerful, set of existential challenges; the danger of major war and climate change can serve as a unifying driver. The values of economic and social equality should again drive policy. Western nations' ostracism of economic and social human rights is not sustainable.

Postcommunist efforts to end impunity of human rights violators through the International Criminal Court have stalled. New projects may have the required practical vision. Justice Richard Goldstone and others are proposing a new global effort to complement the International Criminal Court with systems of evidence collection, and advice and peer review for national and local processes building on the rediscovered practice of the World War II era. ${ }^{26}$

Former president Mikhail Gorbachev's latest warning of nuclear war should propel support for the Treaty on the Prohibition of Nuclear Weapons. However, requirements of the Charter and the demand of the Bandung Conference in 1955 for global governance of all major weapons is answered in the draft Treaty on the Strategic Concept for the Removal of Arms and Proliferation. ${ }^{27}$

One should not wait for these challenges to imperil the world to the point of no return before reviving it and strengthening it in the face of the current attack from populists and "patriots" (to use Trump's words). At the same time, Nehru's warning about the great powers' tendency to return to their old manners of power play despite an apparent show of unity in facing a common danger should remind us that cooperation cannot be based on short-term calculations. Great powers, this time including rising powers like India and China, should lead and be led by others to correct the deficit of multilateralism as the world moves through a momentous period of power transition and transnational imperilment.

\footnotetext{
25 Pugwash Conferences on Science and World Affairs 1955.

26 Plesch and Owen 2019 and www.unwcc.org.

27 Plesch and Miletic 2019 and www.scrapweapons.com.
} 


\section{Bibliography}

Acharya, Amitav. The End of American World Order (Cambridge, UK: Polity, 2014).

Acharya, Amitav, ed. Why Govern: Rethinking Demand and Progress in Global Governance (Cambridge: Cambridge University Press, 2016).

Acharya, Amitav. "After Liberal Hegemony: The Advent of a Multiplex World." Ethics and International Affairs 31 (3) (2017), 271-285.

Adami, Rebecca. Women and the Universal Declaration of Human Rights (London: Routledge, 2018).

Cogburn, Derrick L. “Cyberspace and Social Media." In Why Govern? Rethinking Demand and Progress in Global Governance, ed. Amitav Acharya (Cambridge: Cambridge University Press, 2016), 252-271.

de Coning, Cedric, and Mateja Peter, eds. United Nations Peace Operations in a Changing Global Order (London: Palgrave Macmillan, 2019).

Goldberg, Mark Leon. "Here Is How the UN Is Impacted by the Budget Deal Between President Trump and Congress." IUN Dispatch, 20 February 2019. https://www.undis patch.com/here-is-how-the-un-is-impacted-by-the-budget-deal-between-presiden t-trump-and-congress/.

Helleiner, Eric. "Finance." In Why Govern? Rethinking Demand and Progress in Global Governance, ed. Amitav Acharya (Cambridge: Cambridge University Press, 2016), 174-191.

Keohane, Robert O. After Hegemony: Cooperation and Discord in the World Political Economy (London: Princeton University Press, 1984).

Laidi, Zaki. "What Multipolarity Really Means." http://www.laidi.com/sitedp/sites/defa ult/files/Week\%201.pdf, accessed 15 April 2020.

Luhr Dietrichson, Elise, and Fatima Sator. "Les oubliées de San Francisco." Manière de Voir, December 2016. https://www.monde-diplomatique.fr/mav/150/LUHR_DIETRI CHSON/56861.

Nehru, Jawaharlal. The Discovery of India, 23rd Impression (New Delhi: Oxford University Press, 2003).

Nye, Joseph S. "Will the Liberal Order Survive? The History of an Idea." Foreign Affairs 96 (1) (2017), 10-16.

Peter, Mateja. "UN Peace Operations: Adapting to a New Global Order?" In United Nations Peace Operations in a Changing Global Order, eds. Cedric de Coning and Peter Mateja (London: Palgrave Macmillan, 2019), 1-22. https://www.palgrave.com/ gp/book/9783319991054, accessed 15 April 2020.

Plesch, Dan. America and the UN: How the Allies Won World War II and Forged a Peace (London: I.B. Tauris, 2010a).

Plesch, Dan. America, Hitler and the UN: How the Allies Won World War II and Forged a Peace (London: I.B. Tauris, 2010). 
Plesch, Dan and Owen, Leah (2019) 'The United Nations War Crimes Commission: a model for complementarity today?' In: Griech-polelle, B., (ed.), The Nuremberg War Crimes Trial and its Policy Consequences Today. Baden-Baden: Nomos.

Plesch, Dan and Miletic, K. (2019) 'The Relationship between Humanitarian Disarmament and General and Complete Disarmament.' In: Bolton, M. and BenjaminBritton, T. and Njeri, S., (eds.), Global Activism and Humanitarian Disarmament. Cham: Palgrave, pp. 199-224.

Plesch, Dan, and Thomas G. Weiss, eds. Wartime Origins and the Future United Nations (New York: Routledge, 2015).

Posen, Barry R. "Emerging Multipolarity: Why Should We Care?" Current History 108 (721) (2009), 347-352.

Pugwash Conferences on Science and World Affairs. Russell Einstein Manifesto. 9 July 1955. http://www.spokesmanbooks.com/Spokesman/PDF/85russein.pdf.

Roosevelt, Franklin D. Message to International Labor Organization (FDR speech file 1514a). 19 April 1944a. http://www.fdrlibrary.marist.edu/_resources/images/msf/msf bo144.

Roosevelt, Franklin D. Remarks to Conference of the International Labor Organization (FDR speech file 1517). 17 May 1944b. http://www.fdrlibrary.marist.edu/_resources/ images $/ \mathrm{msf} / \mathrm{msfbo147}$.

Skard, Torild. "Getting Our History Right: How Were the Equal Rights of Women and Men Included in the Charter of the United Nations?" Forum for Development Studies 35 (1) (2011), 37-6o.

Stimson Center, An Innovation Agenda for UN 75: The Albright-Gambari Commission and the Road to 2020 (Washington, DC: Stimson Center, 2019). https://www.stimson .org/content/innovation-agenda-un-75-albright-gambari-commission-report-androad-202O.

Trump, Donald. "Remarks by President Trump to the 74th Session of the United Nations General Assembly." 25 September 2019. https://www.whitehouse.gov/briefings-state ments/remarks-president-trump-74th-session-united-nations-general-assembly/.

United Nations General Assembly. Report of the High-Level Independent Panel on Peace Operations on uniting our strengths for peace: politics, partnership and people. 17 June 2015 https://www.globalr2p.org/resources/report-of-the-high-level-independent-p anel-on-peace-operations-on-uniting-our-strengths-for-peace-politics-partnership -and-people/, accessed ${ }_{15}$ April 2020.

United Nations, "History of the Document" (Universal Declaration of Human Rights): https://www.un.org/en/sections/universal-declaration/history-document/index.ht $\mathrm{ml}$, no date. accessed 15 April 2020.

www.scrapweapons.com Website of the project Strategic Concept for the Removal of Arms and Proliferation.

www.unwcc.org Website of the project on the UN War Crimes Commission of 19431948. 